GGU 134018 B: K-2512. Milne Land

$4610 \pm 90<\mathrm{C}^{13}:-20.0 \%$

Clay gyttja from core of lake sediment. The sample represents the interval $154-165 \mathrm{~cm}$ in a $200 \mathrm{~cm}$ thick deposit of lake gyttja. (Compare GGU 134018 (A): K-1743 from same core, Funder, 1971). Bramgåss $\emptyset$, western Milne Land, $70^{\circ} 31^{\prime} \mathrm{N}, 28^{\circ} 02^{\prime} \mathrm{W}$.

\title{
References
}

Donner, J. \& Jungner, H. 1975: Radiocarbon dating of shells from marine Holocene deposits in the Disko Bugt area, West Greenland. Boreas 4, 25-45.

Funder, S. 1971: $\mathrm{C}^{14}$ dates from the Scoresby Sund region, 1971. Rapp. Grønlands geol. Unders. 37, 57-59.

Håkansson, S. 1975: University of Lund radiocarbon dates VIII. Radiocarbon 17, 174-195.

Jensen, A. S. 1971: Quaternary fossils collected by the Danmark Expedition. Meddr Grønland 43, 619-632.

\section{New instruments for geological photo-interpretation and mapping}

\author{
Keld S. Dueholm
}

\section{Geological photointerpretation and photogrammetry}

Aerial photography is now an integrated part of topographic mapping. Half a century ago photogrammetric methods revolutionised the production of topographic maps, mainly because all contour drawing and measuring of details were transferred from the field to the laboratory. Based on very few field observations, a detailed and very accurate topographic map can be drawn from aerial photographs by photogrammetric methods. Thus, for an area that would require many weeks of field work to produce a satisfactory topographic map, the same result can be achieved in the photogrammetric laboratory in a single day. In addition, accuracy can be very high. For instance, for a map at the scale 1:50 000 an accuracy on the ground better than $0.5 \mathrm{~m}$ can be reached by photogrammetric methods.

Seen photogrammetrically, the drawing of geological maps and the measurement of geological structures do not principally differ from the problems involved in topographic mapping provided of course that the geology can be interpreted or mapped on the photographs. In this respect, it is generally known that the geological exposure offered in Greenland is generally good. Experience in the photo-interpretation of Tertiary plateau basalt areas on Disko in central West Greenland, and Lower Palaeozoic limestone and clastic sediments and Quaternary marine, fluviatile and glacial deposits on Hall Land, North Greenland, has been very positive.

Peculiarly, photogrammetric methods have not become so popular with geologists. Geological interpretation of aerial photographs, together with the measurement of some struc- 
tures by means of simple instruments and methods belong to the daily routine of the field geologist, but more advanced photogrammetric methods tend to be used only by geologists with a background in photogrammetry. It is the present author's opinion that if geological mapping and structural measurements can be carried out with photogrammetric accuracy and effectiveness from aerial photographs, then the mapping of such areas as Greenland, where exposures are generally good, would considerably benefit by its adoption. Such methods would involve a reduction of the field work (as was the case with topographic mapping) as well as make it possible to map otherwise inaccessible terrain. Also to some degree, the quality of the resulting geological map will be independent of the topographic base map.

Naturally, photogrammetric methods as used in topographic mapping require special knowledge and the instruments are expensive as well as being complicated to adapt to geological work. Thus normally, assistance from a photogrammetrist is essential. However, it is now possible to improve the measuring capacity of simple photogrammetric instruments by using computer programming so that the accuracy approaches or even becomes comparable with measurements involving more advanced photogrammetric instruments. By means of interactive table computers photogrammetric calculations can be carried out quickly and simply.

The purpose of this note is to describe a measuring system that can bring such photogrammetric methods within reach of the geologist as a complimentary aid to the routine geological interpretation of aerial photographs.

\section{The stereo-measuring system AMIK}

A table computer having the capacity for photogrammetric calculations - the Hewlett-Packard 9820A - came on the market in 1972. Using this computer and a slightly

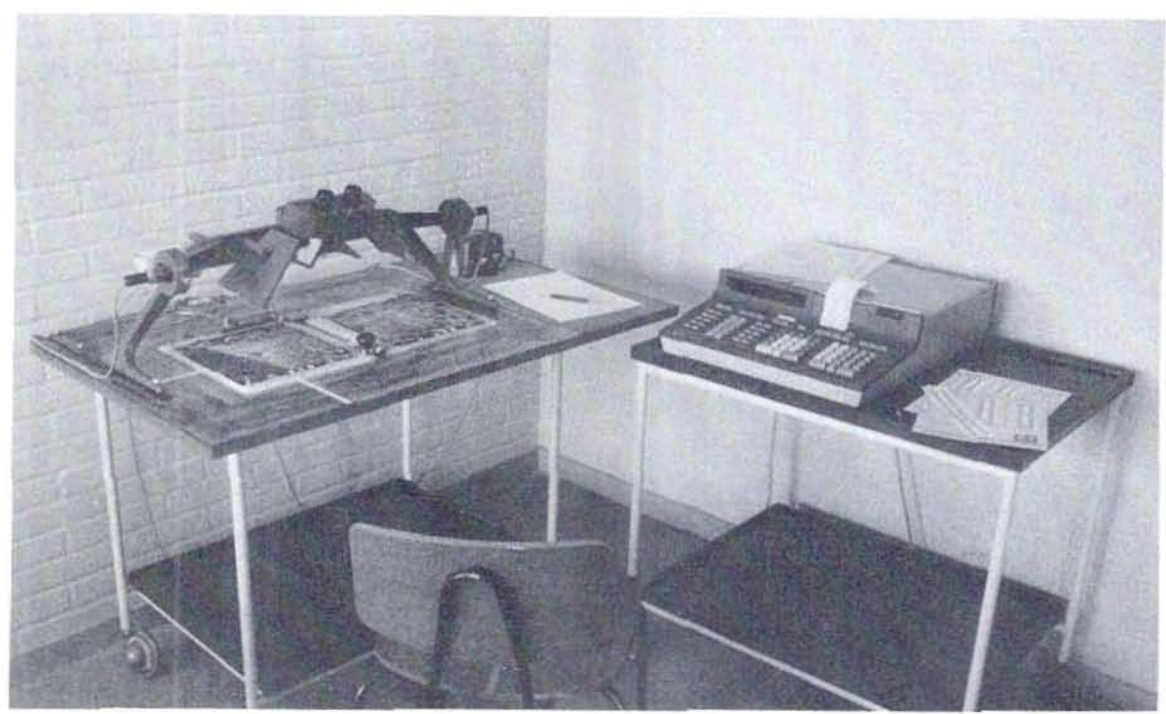

Fig. 44. AMIK - a slightly modified mirror-stereoscope, a table computer and a programme complex. 


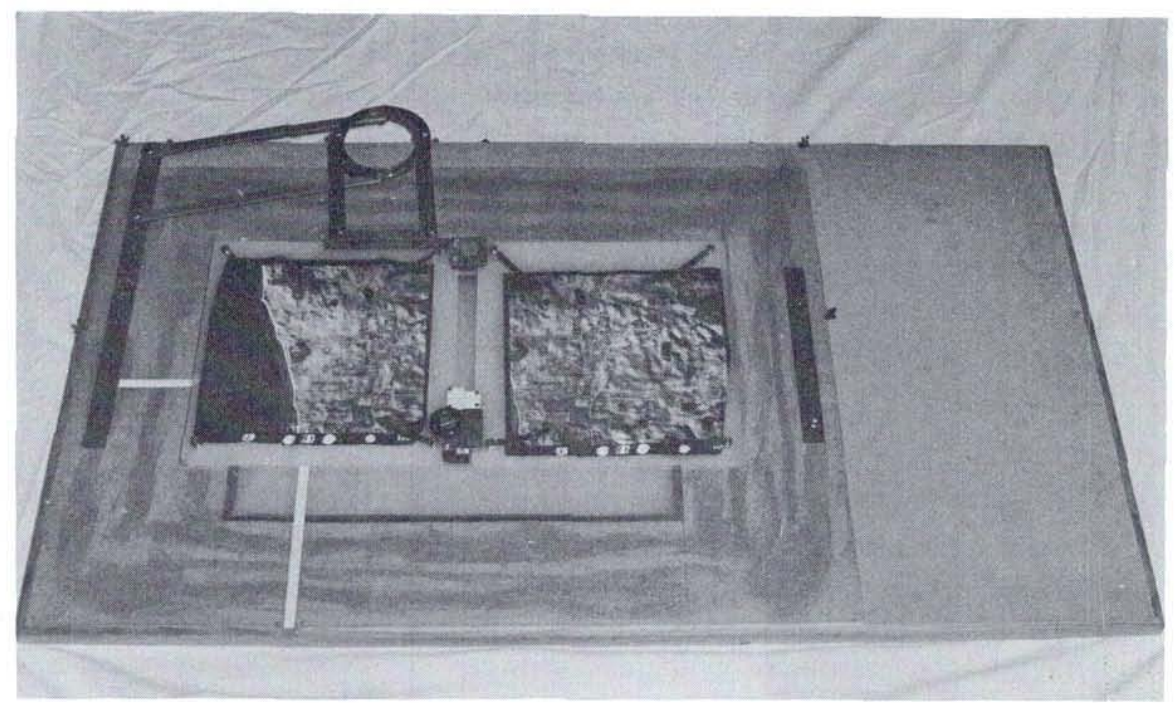

Fig. 45. Modification of the Hilger \& Watts mirror-stereoscope. Two yard-sticks at right angles to each other rest on the table below the moveable photocarriers. A glass plate inserted below is for illumination of diapositives.

modified Hilger \& Watts mirror stereoscope a photogrammetric stereo-measuring system was developed by the author at Danmarks Tekniske Højskole (D. T.H. - Technical University in Copenhagen) (figs $44 \& 45$ ). This system, called AMIK (Analytisk Mini Komparator), has been described in detail elsewhere in Danish (Dueholm, 1976).

By means of a computer programme complex the instrument readings are translated to the terrain coordinates, and by means of a further programme, these are transferred to quantitative geological elements such as strike and dip of strata, axial planes of folds, true stratigraphical thickness of units, etc. Using diapositive photographs at 1:50 000 the terrain coordinates can be determined with a standard error of $4 \mathrm{~m}$ in the horizontal plane and $2 \mathrm{~m}$ in the vertical. It is of some interest to mention here that this geometrical accuracy is about halved if 'normal' paper print photographs are used and there is a corresponding decrease in the amount of geological detail seen.

\section{Operation procedure}

The stereo pair of photographs is placed in the mirror stereoscope in the normal way. By means of a selected measuring and calculation procedure a set of photo-orientation parametres are built up in the computer. For this purpose few field control data are needed. This data may take the form of geodetic triangulation points, either fixed control points or extrapolated from a topographic map, other measurements carried out in connection with geological field work (Dueholm, 1973) or aerotriangulation points. The built up parametres go into a mathematical formula system according to which the image coordinates are transformed into terrain coordinates that are free from scale error, radial displacement and 
photo-tilt. The orientation process takes about 30 minutes after which the measurement of geological elements can take place.

The measuring mark is centred on a chosen geological structure and four readings are taken from the instrument and punched into the table computer. The terrain coordinates for the point are then immediately calculated-a procedure that takes about 1 minute. The whole operation is diagrammatised so that no special photogrammetric knowledge is necessarily required by the operator. Furthermore, the computer programmes are provided with "error finding routines' so that punched errors and measurement inaccuracies become immediately apparent.

\section{Example of application of AMIK}

After the initial construction, AMIK has been thoroughly tested and subsequently used in various geological projects. One such project involved the mapping by Asger Ken Pedersen (Mineralogical Museum, Copenhagen) of $2500 \mathrm{~km}^{2}$ of Tertiary plateau basalts on the island of Disko, central West Greenland as part of GGU's 1:100 000 map sheet, Qutdligssat, 70 V.1, Syd. Following a certain amount of field work in restricted areas, the complete geological map was compiled by AMIK and almost all the geological structures were measured by the method.

The area assigned to the Disko project covers about 100 photogrammetric models at the scale of 1:40 000. In order to fix accurately the structures about 50 to 100 points per model were measured by the geologist himself and on average three models could be so processed each day. Hence, between 150 and 300 geologically relevant determinations covering some $75 \mathrm{~km}^{2}$ were plotted each day. The assembled measurements provide the geologist with a 'data-bank' containing coordinated points in a consistent system covering the entire project area. From this the geological map was constructed and the structural data to be included were selected. The bank also allowed the easy construction of geological profiles, structural cross-sections, as well as volumetric calculations on the basalts.

\section{Zeiss Stereocord G2}

One of the more interesting features of the AMIK system is the devised computer programmes. The Hilger \& Watts mirror-stereoscope was chosen in 1972 because at that time no better or more sophisticated instrument was on the market at a comparable price. However, one of the disadvantages of AMIK, is that the transference of data from the stereoscope to the table calculator has to be done manually. Electronic transference of the data would naturally make the system easier and faster to work.

Zeiss of West Germany have now introduced a system - the Stereocord G2 - that is essentially of the same type as AMIK. It has been constructed by the addition of a devise for the automatic registration of coordinates to an earlier model - the Stereoopret. The electronic part of the apparatus consists of a Hewlett-Packard table calculator model 9810 or 9830 and a programme which handles approximate photogrammetric solutions. From the information now available it seems that the system is a good alternative to AMIK, the elctronic 
transference of coordinates offered by the Zeiss instrument is a definite advantage. However, the Stereocord G2 is considerably more expensive than AMIK.

\section{Plotting of contour and geological structures}

An automatic plotter is standard equipment for a Hewlett-Packard table computer. The calculator $9820 \mathrm{~A}$ has the capacity to handle the automatic drawing of contours by the plotter from the point measurements made in AMIK or Stereocord G2. For this purpose a contour drawing routine has been developed.

Using the table calculator $9820 \mathrm{~A}$, a magnetic tape station and the automatic plotting equipment, it is now possible to transform the point measurement from the photogrammetric model into a contour map on an orthogonal projection with a freely chosen contour distance. In the same way, geological structures can be measured and plotted directly on the topography.

\section{Final comments}

The use of AMIK in geological projects in Greenland has shown that such photogrammetric methods considerably increase the amount of geological mapping and compilation that càn satisfactorily be carried out in the laboratory, and thereby reduces the time spent on mapping in the field. Furthermore, the amount of detail which can be interpreted and accurately plotted results in a high accuracy of the mapping. Moreover, the method makes it possible to compile good and accurate geological maps in regions covered only by low quality topographic maps.

The experience gained in the development and application of AMIK has led to attempts at more advanced photogrammetric methods on geological work. For example, stereoscopic plotting instruments have been used for the drawing of geological structures in orthogonal projection and a stereo-comparator has been used to zoom down on areas of special interest in order to make very detailed and accurate structural measurements (Dueholm \& Pedersen, in prep; Dueholm \& Ulff-Møller, in prep.). These methods require close cooperation between geologist and photogrammetrist, in contrast to AMIK which can be operated solely by a geologist.

\section{References}

Dueholm, K. S. 1973: Untraditional topographic mapping in central West Greenland. Rapp. Grønlands geol. Unders. 65, 26-28.

Dueholm, K. S. 1976: AMIK, Analytisk Minikomparator. Meddr Inst. Landmåling og Fotogrammetri, D. T. H. 8, 73 pp.

Dueholm, K. S. \& Pedersen, A. K. in prep.: High precision photogrammetric methods used in regional geological mapping. Rapp. Grønlands geol. Unders.

Dueholm, K. S. \& Ulff-Møller, F. in prep.: High precision photogrammetric methods used in detailed geological mapping. Rapp. Grønlands geol. Unders.

Instituttet for Landmåling og Fotogrammetri, Danmarks Tekniske Højskole, Landmålervej 7, 2800 Lyngby. 